\title{
Mollaret's Meningitis
}

\author{
J.M.S. Pearce \\ Emeritus Consultant Neurologist, Department of Neurology, Hull Royal Infirmary, Hull, UK
}

\section{Key Words}

Mollaret's meningitis - Recurrent aseptic meningitis •

HSV-2 virus

\begin{abstract}
Pierre Mollaret is mainly known for his contributions to infectious diseases and their prevention. He also described benign, recurrent endothelio-leukocytic meningitis in three patients who had short-lived recurrent attacks of fever, headache and vomiting caused by sterile meningitis, with 'fantomes cellulaires' (cell ghosts) in the cerebrospinal fluid. Identical symptoms are caused by Herpes simplex virus-2 and other viruses. The term Mollaret's meningitis should be restricted to idiopathic recurrent aseptic meningitis. This paper briefly outlines the syndrome and its discoverer.
\end{abstract}

Copyright $\odot 2008$ S. Karger AG, Basel

From a long career, Pierre Mollaret is remembered by neurologists mainly for two contributions. The first, discussed in this issue [1], was his anatomical description of the connections between the dentate nucleus, red nucleus and the contralateral inferior olivary nucleus (the Guillain-Mollaret triangle) [2] and its relation to palatal myoclonus [3]. The second came in 1944, when he described in three adult patients recurrent benign endothelio-leukocytic aseptic meningitis, a syndrome of brief attacks of meningitis with no evident cause [4]. Mollaret wrote several subsequent papers on this condition, which acquired

\section{KARGER}

Fax +4161306 1234

E-Mail karger@karger.ch

www.karger.com
(C) 2008 S. Karger AG, Basel

0014-3022/08/0606-0316\$24.50/0

Accessible online at:

www.karger.com/ene his name [5]. He observed peculiar cells in the cerebrospinal fluid (CSF), which he called 'fantomes cellulaires' (cell ghosts). All three patients had short-lived attacks of fever, headache and vomiting, meningeal irritation, and generalized myalgia.

\section{Mollaret's Meningitis}

Mollaret's meningitis is rare - only 32 cases were reported in 1982, the same year that the herpes virus was inculpated in a case report [6]. It is characterized by recurrent attacks of sudden onset meningitis that usually last for 2-7 days, with complete recovery but unpredictable recurrences. Alternative names are: benign recurrent aseptic meningitis; benign recurrent endothelial meningitis, and benign recurrent endothelial-leukocytic meningitis. In the first $24 \mathrm{~h}$, large mononuclear cells with blunt pseudopods and bean-shaped, bilobed nuclei termed 'Mollaret's cells' - are typical in the CSF, but may be absent. Using electron microscopy, de Chadarévian and Becker [7] proved that Mollaret's endothelial cells were 'epitheloid-looking monocytes or macrophages'. Other examples of these cells have proved to be secondary to dermoid or epidermoid tumours [8] sited near the ventricles or spinal CSF; they may precipitate the leakage of tumour elements into the subarachnoid space and cause a recurrent chemical meningitis [9]. Recurrent Herpes simplex virus (HSV-2, less often HSV-1) meningitis is clinically indistinguishable from cases of idiopathic Mollaret's meningitis [10, 11]. In most herpetic 
cases, HSV-2 DNA is present in the CSF, and can be detected by polymerase chain reaction (PCR). Echo, Coxsackie, and Epstein-Barr viruses have been identified in some instances.

The term 'Mollaret's meningitis' should, therefore, be restricted to idiopathic recurrent aseptic meningitis; whereas cases of recurrent meningitis known to be associated with HSV or, rarely, other viruses should be referred to as 'recurrent viral meningitis'. Acyclovir, valacyclovir, and famciclovir have been given to some patients but there is no controlled trial data to support their efficacy in preventing attacks.

Prof. Julien Bogousslavsky has perhaps the longest follow-up of a patient with Mollaret's meningitis. The patient started her episodes in 1945, at the age of 20, and was followed up by Raymond Adams in the 1970s. She had her last attack in 2006.

\section{Pierre Mollaret (1898-1987)}

Mollaret was a French physician of infectious diseases, who made important contributions to the management of malaria and poliomyelitis. He was born in Auxerre, France, on 10 July 1898 . He started his medical studies in 1916, but was soon called to serve in World War I and was awarded the Croix de Guerre. Returning to
Medicine, he graduated in 1926 and began a long association with his former teacher, Georges Charles Guillian (1876-1961).

In 1929 he obtained his medical doctorate and became chef de clinique at the Hôpital de la Salpêtrière, where he directed malaria therapy. He also worked from 1935 to 1941 as head of the laboratory at the Pasteur Institute, becoming professeur agrégé in 1936, and was chef de service from 1941 to 1946 . He was appointed secrétaire général of Revue Neurologique in 1938. During World War II he was chief medical officer in an army laboratory and in the malaria department of the military hospital in Casablanca. After the war he held the Chair of Infectious Diseases at the Claude Bernard Hospital in Paris.

In 1952, Dr. Pierre Lépine, of the Pasteur Institute, asked for Mollaret's help in dealing with an epidemic of poliomyelitis in Scandinavia. With Jacques Pocidalo, he prepared a centre to cater for cases with respiratory paralysis, using the new Engström respirators. Via tracheotomies they regulated ventilation and rapidly monitored and controlled plasma oxygen and carbon dioxide levels. This improved the outcome and survival of many polio patients in the French epidemic of 1954. He also developed an antigen for intradermal testing of cat-scratch disease (Bartonella henselae).

Mollaret died in Montgeron, near Paris, in 1987.

\section{References}

1 Pearce JMS: Palatal myoclonus (syn. Palatal Tremor). Eur Neurol 2008;60:312-315.

2 Sarikcioglu L, Sindel M: Pierre Mollaret (1898-1987) and his legacy to science. J Neurol Neurosurg Psychiatry 2007;78:1135.

3 Guillain G, Mollaret P: Deux cas de myoclonies synchrones et rythmées vélo-pliaryngo-oculo-diaphragmatiques. Le problème anatomique et physio-pathologique de ce syndrome. Rev Neurol (Paris) 1931;2:545566.

4 Mollaret P: La meningite endothelio-leucocytaire multirecurrente benigne. Syndrome nouveau ou maladie nouvelle. Documents clinique. Rev Neurol (Paris) 1944;76:57-76.
Mollaret P: La méningite endothelio leukocytaire multirécurrente bénigne. Rev Neurol 1977;133:225-244.

-6 Steel JG, Dix RD, Baringer JR: Isolation of herpes simplex virus type 1 in recurrent (Mollaret) meningitis. Ann Neurol 1982;11: $17-21$.

7 de Chadarévian JP, Becker WJ: Mollaret's recurrent aseptic meningitis: relationship to epidermoid cysts. Light microscopic and ultrastructural cytological studies of the cerebrospinal fluid. Neuropathol Exp Neurol. 1980;39:661-669.
Gao B, Yang J, Zhuang S, Deng Y, et al: Mollaret meningitis associated with an intraspinal epidermoid cyst. Pediatrics 2007;120: E220-E224.

9 Frederics JAM, Bruyn GW: Mollaret's meningitis; in Vinken PJ, Bruyn GV (eds): Handbook of Clinical Neurology, vol 34. Amsterdam, North Holland, 1978, pp 545-552.

10 Tyler KL: Herpes simplex virus infections of the central nervous system: encephalitis and meningitis, including Mollaret's. Herpes 2004;11(Suppl 2):57A-64A.

11 Ellerin TB, Walsh SR, Hooper DC: Recurrent meningitis of unknown aetiology. Lancet 2004;363:1772. 